\title{
Reference of serum insulin level and prevalence of insulin resistance of Korean children and adolescents
}

\author{
Jung Sub Lim*, Ju Hee Seo, Jun Ah Lee, Dong Ho Kim \\ From 7th APPES Biennial Scientific Meeting \\ Nusa Dua, Bali. 14-17 November 2012
}

\section{Objective}

This study was to examine the distribution of insulin and homeostasis model assessment of insulin resistance (HOMA-IR) and decide insulin resistance cut off of Korean children and adolescents.

\section{Research Design and Methods}

Data from 2,716 subjects (1,421 male, 1,295 female; age range, 10-20 years) in Korea National Health and Nutrition Examination Survey IV (2007-2009) were evaluated. The reference values of insulin and HOMA-IR of normal weight subjects were made according to sex, age and weight status. Insulin resistance was defined as HOMA-IR > 95 percentile. The odds ratios of metabolic syndrome and its components were assessed based on insulin resistance state.

\section{Results}

Insulin and HOMA-IR values appear to peak at age 1314 years in male and age 12-13 years in female subjects. Female had lower fasting glucose and higher insulin $(\mathrm{P}=0.049)$ than male. Thus, HOMA-IR between sex was not different $(P=0.257)$. Overweight and obese subjects had higher HOMA-IR compared with subjects of normal weight (3.83 [95\% CI 3.64-4.02], 5.16 [95\% CI 4.70-5.62], and 2.66 [2.62-2.71], respectively). The prevalence of insulin resistance in total subjects was 9.7\% (male; $10.9 \%$, vs. female; $8.6 \%$ ). The prevalence of insulin resistance in normal-weight, overweight and obese subjects were $4.7 \%, 25.6 \%$, and $47.1 \%$ respectively. Subject with insulin resistance had more metabolic

syndrome (odds ratios, 18.33 [95\% CI 9.62-34.94]) and its components.

\section{Conclusions}

Insulin and HOMA-IR values vary depending on sex, age, and weight status. Obesity is the most important risk factor for insulin resistance, but number of insulin resistance subject in normal-weight subject were compatible to those. This information may be useful in not only Korean but also Asian planning programs for the prevention of type 2 diabetes from childhood.

Published: 3 October 2013

doi:10.1186/1687-9856-2013-S1-P99

Cite this article as: Lim et al:: Reference of serum insulin level and prevalence of insulin resistance of Korean children and adolescents. International Journal of Pediatric Endocrinology 2013 2013(Suppl 1):P99.

Submit your next manuscript to BioMed Central and take full advantage of:

- Convenient online submission

- Thorough peer review

- No space constraints or color figure charges

- Immediate publication on acceptance

- Inclusion in PubMed, CAS, Scopus and Google Scholar

- Research which is freely available for redistribution

\section{Biomed Central}

